\title{
Tributyltin impacts in Galapagos Islands and Ecuadorian shore: Marine protected areas under threat
}

\author{
René Oscar Rodríguez Grimón ${ }^{\mathrm{a}}$, María Fernanda Arroyo Osorio ${ }^{\mathrm{b}}$, Débora M. de Freitas ${ }^{\mathrm{c}}$, \\ Ítalo Braga Castro ${ }^{\mathrm{d}, *}$
}

${ }^{a}$ Escuela de Ciencias Ambientales, Universidad de Especialidades Espíritu Santo, Guayaquil, Ecuador

${ }^{\mathrm{b}}$ Instituto de Investigaciones de Recursos Naturales, Universidad de Guayaquil, Guayaquil, Ecuador

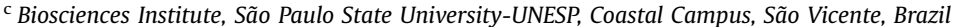

${ }^{\mathrm{d}}$ Instituto do Mar, Universidade Federal de São Paulo, Santos, Brazil

\section{A R T I C L E I N F O}

\section{Article history:}

Received 1 February 2016

Received in revised form

17 March 2016

Accepted 17 March 2016

Available online 24 March 2016

Keywords:

Antifouling paints

Regulations

Harbor areas

Marine protected areas

Imposex

\begin{abstract}
A B S T R A C T
Imposex incidence and biometric parameters were investigated in six muricid species along of $1200 \mathrm{~km}$ of Ecuadorian shore and in Galapagos archipelago. The obtained data, were compared to previous studies performed in the same area in 2009. The results showed that moderate imposex levels still occur in coastal areas of Ecuador, even after global TBT ban. However, a reduction in imposex parameters was detected in the sampled sites, indicating probably relationship to the global TBT ban issued by IMO at 2008. On the other hand, the levels currently reported in present study indicates that TBT environmental concentrations are still high enough to produce biological effects in studied areas. In addition, imposex incidence in four muricid species from Galapagos islands were detected suggesting that this marine protected area is under threat of antifouling contamination. These findings, after TBT global ban, denotes that current regulations and conservation plans still need to address such an issue and incorporate more restrictive management rules, particularly in complex coastal areas, vulnerable and unique systems such as the Galapagos Islands.
\end{abstract}

(c) 2016 Elsevier Ltd. All rights reserved.

\section{Introduction}

Antifouling paints are used as protective coatings in hulls of ships, aquaculture nets, offshore structures, and ducts in order to minimize problems related fouling adhesion. The biofouling settlement increase the corrosion rates, fuel consumption and affects the navigability by ships and boats [1]. The antifouling paints formulations include chemical biocides, which may be released into the aquatic ecosystems causing several environment damages [2]. Historically, the most useful biocide used in antifouling paints was the Tributyltin (TBT). This compound is a toxic synthetic organic molecule recognized by its antifouling efficiency and wide biocide spectrum of action against fouling communities. Thus, antifouling paints TBT-based were extensively used starting in the 1970s [3]. However, TBT has been described as the most toxic substance that has never been introduced deliberately in the marine environments [4]. Accordingly, TBT contamination has

\footnotetext{
* Correspondence to: Ítalo Braga Castro, UNIFESP - Instituto do Mar, Avenida Almirante Saldanha da Gama, 89, Ponta da Praia, Santos-SP 11030400, Brazil.

E-mail addresses: rrodriguez@uees.edu.ec (R.O. Rodríguez Grimón), megapitaria@hotmail.com (M.F. Arroyo Osorio),

freitas.debora@gmail.com (D.M. de Freitas), italobraga@gmail.com (Í.B. Castro).
}

been related to several deleterious effects on marine biota such as oyster malformation [5], immuntoxicity in fish and mammals [6], imposex [7] and decline of gastropod populations [8]. Hence, the International Maritime Organization (IMO), through of the antifouling systems (AFS) convention, banned in September 2008 the use of antifouling paints TBT-based worldwide [9].

The imposex is an endocrine disruption (penis and vas deferens development in females) frequently detected in gastropods, particularly muricids, exposed to TBT $[10,11]$. Due to the early response, easy detection, and dose-dependent relationship with environmental levels of TBT, imposex have been used as a useful tool for monitoring of TBT pollution worldwide [12]. In South America, several recent studies have detected butyltin contamination based on imposex and chemical determinations from environmental samples [4], including temporal approaches after the TBT word ban [13]. However, most of these studies were performed on the Atlantic coast [14-16] where currently the impact of antifouling paints TBT-based is relatively well known [4]. In contrast, to Pacific coastal zones of the South America, there are few investigations on imposex and TBT contamination $[17,18]$. In addition, despite the importance to verify the effectiveness of restrictive legislations, temporal evaluations of imposex occurrence and/or TBT levels in marine protected and unprotected areas, still 
not performed in the region.

In the Ecuador coastal areas and in Galapagos islands, there are several maritime ship/boat traffic areas, mainly commercial, touristic and fishing harbors [19]. The country has no restrictions on antifouling application (including TBT) since it is not a signatory of the international convention on the control of harmful antifouling systems on ships [20]. Thus, these areas are highly susceptible to contamination by biocides from antifouling paints. In fact, a monitoring study performed in 2009 at Gulf of Guayaquil, showed high imposex incidence in Thais kiosquiformis associated to moderate TBT concentrations in surface sediments [17]. Therefore, the present study aimed to verify the temporal evolution of imposex parameters (2009-2012) in the same areas previously affected by imposex occurrence, as well as expand, the sampling grid in order to assess the imposex occurrence in different muricid species throughout Ecuadorian coast and Galapagos islands. In addition, an overview on the effectiveness of the antifouling convection to marine protected areas, and implications of the imposex occurrence in Galapagos island is provided in this paper.

\section{Materials and methods}

\subsection{Sampling}

Thirteen sample sites distributed along approximately $1200 \mathrm{~km}$ inside the Gulf of Guayaquil and adjacent coastal area of Ecuador were selected. Other 3 sites located in Galapagos archipelago (Santa Cruz (P13) and San Cristobal islands (P14-P15)) were also sampled (Fig. 1). The choice of the sampled sites was based on the occurrence of ship/boat activities as well as in a prior study performed in coastal area of Ecuador during 2009. At each sampling site, whenever possible 30 adult individuals of muricid gastropods (Thais brevidentata, T. biserialis, T. kiosquiformis, T. melones, Plicopurpura patula and Plicopurpura columellaris) were caught (either manually or by free diving) between June and December 2012.

\subsection{Biometric and Imposex analysis}

In the laboratory, snails shell length (SL) was measured from the apex to the extremity of the siphonal canal using a vernier caliper. Animals were then narcotized in $3.5 \% \mathrm{MgCl}_{2}$ solution [21] and soft parts extracted from the shells. Sexual identification was done by the presence of sperm ingesting gland, albumen and capsule glands in females and prostate in males. Penis length (PL) was measured to the nearest millimeter using calipers in both males and imposex-affected females. The imposex levels were assessed using initially four traditional indices. The imposex percentage $(\% \mathrm{I})$, which was calculated as the proportion of females imposex affected compared to the total number of females in the sample. The female penis length Index (FPLI = mean penis length of all females in the sample, including the zero values of aphalic females). The relative penis length index (RPLI) obtained by equation RPLI $=$ [mean penis length in females / mean penis length in males] x 100 [22]. The vas deferens sequence index (VDSI) was assessed according to Toste et al. [23].

\subsection{Data analysis}

FPLI and RPLI uses biometric parameters witch may be influenced by differences in organism sizes [24]. Thus, the occurrence of statistical relationship between shell length (SL) and penis length (PL) was investigated by exponential regression considering all organisms of each species. Afterwards, a Kruskal-Wallis multicomparative independent test was done for compares SL from different sites. Considering the occurrence of statistical correlation between PL and SL for all muricid studied, as well as, some populations presented different sizes (see results) a SL standardized

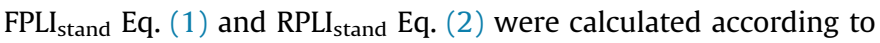
Castro and Fillmann 2012 [18] by following equations.

$F P L I_{\text {stand }}=$ FPLI/female $S L$

$R P L I_{\text {stand }}=\frac{(\text { Mean female PL } / \text { mean female SL })}{(\text { Mean male PL } / \text { mean male SL })} \times 100$

Paired Mann-Whitney tests were used to compare VDSI values between the sampling campaigns performed in 2009 and 2012. Prior the statistical analyses, the normality and homogeneity of data (SL, PL and VDSI) were verified using Shapiro-Wilk and Levene tests, respectively. All statistical analyses were performed using Statistica ${ }^{\circledR}$ (version 12.0 (Statsoft)) with a significant level of 0.05 .

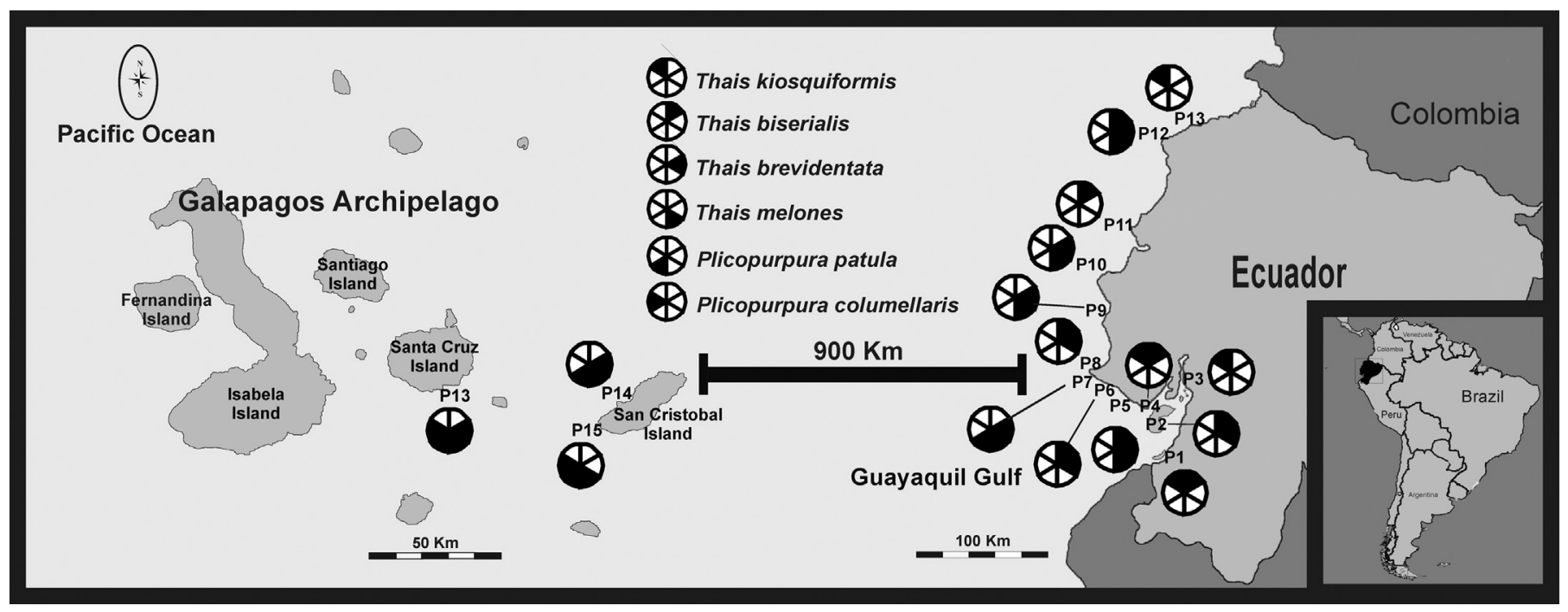

Fig. 1. Sampling sites (P) of muricid gastropods (T. brevidentata, T. biserialis, T. kiosquiformis T. melones, P. columellaris and P. patula) in the Ecuadorian coastal shore and Galapagos Islands. 


\section{Results and discussion}

\subsection{Biometric data and imposex parameters}

Biometric and imposex parameters for muricid species from Ecuadorian coastal shore and Galapagos Islands are summarized in the Table 1. Penis length in males and females of Thais brevidentata, T. biserialis, T. kiosquiformis, T. melones, Plicopurpura patula and $P$. columellaris from the studied populations demonstrated to be dependent on shell size (Fig. 2).

The relatively lower regression coefficient $\left(r^{2}\right)$ for females of all species was due to the low imposex levels observed in studied areas, since PL in imposex females is TBT dependent and not SL dependent (see below). Additionally, significant variations were found between muricid shells sizes (of the same species) obtained from different sites (Kruskal-Wallis, $p<0.05$ ) in both, Ecuadorian

Table 1

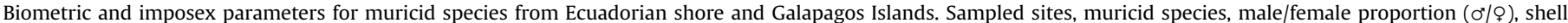

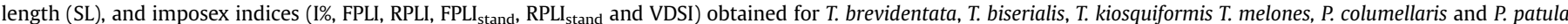

\begin{tabular}{|c|c|c|c|c|c|c|c|c|c|c|}
\hline \multirow[t]{2}{*}{ Sampled sites ( $\mathrm{x}, \mathrm{y}$ coordinates) } & \multirow[t]{2}{*}{ Species } & \multirow[t]{2}{*}{$\mathrm{n}\left(\sigma^{\prime} / q\right)$} & \multicolumn{2}{|c|}{$\mathbf{S L} \pm \mathbf{S D}(\mathbf{m m})$} & \multirow[t]{2}{*}{ I (\%) } & \multirow{2}{*}{ FPLI \pm SD (mm) } & \multirow[t]{2}{*}{ RPLI } & \multirow[t]{2}{*}{ FPLI $_{\text {stand }}$} & \multirow[t]{2}{*}{ RPLI $_{\text {stand }}$} & \multirow[t]{2}{*}{ VDSI } \\
\hline & & & males & females & & & & & & \\
\hline \multicolumn{11}{|l|}{ Ecuador Coastal Areas } \\
\hline $\mathrm{P}^{1}-$ Bolivar harbor $(-610,826,9638863)$ & $\begin{array}{l}\text { T. biserialis } \\
\text { T. kiosquiformis }\end{array}$ & $\begin{array}{l}15 / 15 \\
11 / 15\end{array}$ & $\begin{array}{l}39.8 \pm 4.1 \\
39.8 \pm 3.5\end{array}$ & $\begin{array}{l}41.4 \pm 5.1 \\
42.0 \pm 3.7\end{array}$ & $\begin{array}{l}100 \\
100\end{array}$ & $\begin{array}{l}2.21 \pm 1.68 \\
3.20 \pm 1.42\end{array}$ & $\begin{array}{l}15.6 \\
21.8\end{array}$ & $\begin{array}{l}0.05 \\
0.08\end{array}$ & $\begin{array}{l}15.0 \\
20.7\end{array}$ & $\begin{array}{l}2.05 \pm 1.00 \\
2.10 \pm 1.20\end{array}$ \\
\hline $\begin{array}{l}P^{2}-\text { Isla Puná }(-582,671,9687176) \\
P^{3}-\text { Guayaquil harbor }(-624,059,9747352)\end{array}$ & $\begin{array}{l}\text { T. brevidentata } \\
\text { T. biserialis } \\
\text { T. kiosquiformis }\end{array}$ & $\begin{array}{l}8 / 22 \\
11 / 19 \\
13 / 17\end{array}$ & $\begin{array}{l}27.3 \pm 1.3 \\
30.9 \pm 1.1 \\
43.7 \pm 4.8\end{array}$ & $\begin{array}{l}27.1 \pm 1.7 \\
33.1 \pm 5.8 \\
42.2 \pm 5.9\end{array}$ & $\begin{array}{l}16 \\
32 \\
94\end{array}$ & $\begin{array}{l}0.58 \pm 1.39 \\
1.18 \pm 1.79 \\
1.48 \pm 2.00\end{array}$ & $\begin{array}{l}14.5 \\
27.0 \\
9.9\end{array}$ & $\begin{array}{l}0.02 \\
0.04 \\
0.04\end{array}$ & $\begin{array}{l}14.6 \\
25.2 \\
10.6\end{array}$ & $\begin{array}{l}0.35 \pm 0.70 \\
0.47 \pm 0.8 \\
0.96 \pm 0.60\end{array}$ \\
\hline $\mathrm{P}^{4}-$ Posorja $(-584,140,9700153)$ & $\begin{array}{l}\text { T. biserialis } \\
\text { T. kiosquiformis }\end{array}$ & $\begin{array}{l}12 / 18 \\
10 / 20\end{array}$ & $\begin{array}{l}35.3 \pm 3.4 \\
35.0 \pm 4.2\end{array}$ & $\begin{array}{l}33.5 \pm 3.8 \\
33.4 \pm 3.0\end{array}$ & $\begin{array}{l}100 \\
100\end{array}$ & $\begin{array}{l}0.26 \pm 0.48 \\
2.44 \pm 2.35\end{array}$ & $\begin{array}{l}5,7 \\
55.5\end{array}$ & $\begin{array}{l}0.01 \\
0.07\end{array}$ & $\begin{array}{l}5.9 \\
58.5\end{array}$ & $\begin{array}{l}0.20 \pm 0.10 \\
2.12 \pm 1.00\end{array}$ \\
\hline $\mathrm{P}^{5}$ - Playas $(-564,009,9708153)$ & $\begin{array}{l}\text { T. brevidentata } \\
\text { T. biserialis } \\
\text { T. melones }\end{array}$ & $\begin{array}{l}2 / 28 \\
2 / 28 \\
2 / 4\end{array}$ & $\begin{array}{l}23.3 \pm 0.9 \\
27.4 \pm 0.5 \\
29.5 \pm 0.7\end{array}$ & $\begin{array}{l}26.0 \pm 3.9 \\
28.1 \pm 2.2 \\
21.3 \pm 3.9\end{array}$ & $\begin{array}{l}0 \\
32 \\
0\end{array}$ & $\begin{array}{l}0.00 \\
1.30 \pm 2.16 \\
0.00\end{array}$ & $\begin{array}{l}0.0 \\
29.4 \\
0.0\end{array}$ & $\begin{array}{l}0.00 \\
0.05 \\
0.00\end{array}$ & $\begin{array}{l}0.0 \\
28.7 \\
0.0\end{array}$ & $\begin{array}{l}0.00 \\
0.52 \pm 0.65 \\
0.00\end{array}$ \\
\hline $\mathrm{P}^{6}-$ Chanduy $(-535,031,973459)$ & $\begin{array}{l}\text { T. brevidentata } \\
\text { T. biserialis }\end{array}$ & $\begin{array}{l}7 / 23 \\
3 / 27\end{array}$ & $\begin{array}{l}25.8 \pm 1.1 \\
35.5 \pm 0.6\end{array}$ & $\begin{array}{l}26.8 \pm 2.1 \\
28.2 \pm 3.3\end{array}$ & $\begin{array}{l}13 \\
52\end{array}$ & $\begin{array}{l}0.01 \pm 0.03 \\
0.79 \pm 1.01\end{array}$ & $\begin{array}{l}0.3 \\
1.5\end{array}$ & $\begin{array}{l}<0.01 \\
0.03\end{array}$ & $\begin{array}{l}0.3 \\
1.8\end{array}$ & $\begin{array}{l}0.02 \pm 0.05 \\
0.45 \pm 0.36\end{array}$ \\
\hline $\mathrm{P}^{7}$ - Punta Carnero $(-510,847,9747433)$ & $\begin{array}{l}\text { T. brevidentata } \\
\text { T. melones } \\
\text { P. patula }\end{array}$ & $\begin{array}{l}8 / 22 \\
1 / 5 \\
11 / 19\end{array}$ & $\begin{array}{l}20.0 \pm 1.4 \\
19.4 \pm 0.0 \\
28.7 \pm 5.8\end{array}$ & $\begin{array}{l}20.4 \pm 1.3 \\
20.7 \pm 2.2 \\
26.1 \pm 4.5\end{array}$ & $\begin{array}{l}9 \\
60 \\
5\end{array}$ & $\begin{array}{l}0.01 \pm 0.03 \\
0.62 \pm 0.88 \\
0.05 \pm 0.23\end{array}$ & $\begin{array}{l}0.3 \\
0.2 \\
0.6\end{array}$ & $\begin{array}{l}<0.01 \\
0.03 \\
<0.01\end{array}$ & $\begin{array}{l}0.3 \\
0.2 \\
0.6\end{array}$ & $\begin{array}{l}0.02 \pm 0.01 \\
0.44 \pm 0.42 \\
0.01 \pm 0.01\end{array}$ \\
\hline $\mathrm{P}^{8}$ - La Libertad ( - 511,001,9753104) & $\begin{array}{l}\text { T. brevidentata } \\
\text { T. biserialis }\end{array}$ & $\begin{array}{l}12 / 10 \\
2 / 25\end{array}$ & $\begin{array}{l}21.4 \pm 2.8 \\
27.4 \pm 1,7\end{array}$ & $\begin{array}{l}22.3 \pm 3.5 \\
26.4 \pm 3.0\end{array}$ & $\begin{array}{l}10 \\
36\end{array}$ & $\begin{array}{l}0.10 \pm 0.32 \\
0.60 \pm 1.57\end{array}$ & $\begin{array}{l}2.2 \\
21.8\end{array}$ & $\begin{array}{l}<0.01 \\
0.04\end{array}$ & $\begin{array}{l}2.1 \\
22.6\end{array}$ & $\begin{array}{l}0.01 \pm 0.01 \\
0.53 \pm 0.64\end{array}$ \\
\hline P9 - Puerto López (-520,306,9828476) & $\begin{array}{l}\text { T. brevidentata } \\
\text { T. melones }\end{array}$ & $\begin{array}{l}7 / 23 \\
5 / 25\end{array}$ & $\begin{array}{l}20.5 \pm 0.6 \\
25.4 \pm 1.4\end{array}$ & $\begin{array}{l}21.0 \pm 1.1 \\
25.4 \pm 2.9\end{array}$ & $\begin{array}{l}0 \\
20\end{array}$ & $\begin{array}{l}0.00 \\
0.36 \pm 0.81\end{array}$ & $\begin{array}{l}0.0 \\
6.7\end{array}$ & $\begin{array}{l}0,00 \\
0.01\end{array}$ & $\begin{array}{l}0.0 \\
6.7\end{array}$ & $\begin{array}{l}0.00 \\
0.12 \pm 0.25\end{array}$ \\
\hline $\begin{array}{l}\mathrm{P}^{10} \text { - Manta harbor }(-531,422,98984) \\
\mathrm{P}^{11} \text { - Bahía de Caráquez }(-564,785,9933637)\end{array}$ & $\begin{array}{l}\text { T. brevidentata } \\
\text { T. melones } \\
\text { T. biserialis }\end{array}$ & $\begin{array}{l}4 / 26 \\
4 / 26 \\
4 / 14\end{array}$ & $\begin{array}{l}32.7 \pm 2.8 \\
39.8 \pm 3.0 \\
28.0 \pm 0.5\end{array}$ & $\begin{array}{l}32.1 \pm 2.6 \\
39.0 \pm 5.9 \\
27.6 \pm 10.4\end{array}$ & $\begin{array}{l}46 \\
35 \\
93\end{array}$ & $\begin{array}{l}2.35 \pm 2.38 \\
1.58 \pm 2.66 \\
2.64 \pm 3.6\end{array}$ & $\begin{array}{l}36.1 \\
14.0 \\
70.3\end{array}$ & $\begin{array}{l}0.07 \\
0,04 \\
0.10\end{array}$ & $\begin{array}{l}36.8 \\
14.3 \\
71.3\end{array}$ & $\begin{array}{l}0.95 \pm 0.95 \\
0.68 \pm 0.74 \\
0.95 \pm 0.90\end{array}$ \\
\hline $\mathrm{P}^{13}$ - Esmeraldas harbor $(-650,453,109039)$ & $\begin{array}{l}\text { T. brevidentata } \\
\text { T. melones } \\
\text { T. biserialis } \\
\text { T. kiosquiformis }\end{array}$ & $\begin{array}{l}17 / 13 \\
1 / 12 \\
12 / 19 \\
0 / 2\end{array}$ & $\begin{array}{l}24.2 \pm 1.9 \\
25.3 \pm 0.0 \\
21.6 \pm 1.8 \\
\text { na }\end{array}$ & $\begin{array}{l}25.5 \pm 3.0 \\
26.4 \pm 3.6 \\
21.9 \pm 2.2 \\
50.5 \pm 9.1\end{array}$ & $\begin{array}{l}0 \\
25 \\
21 \\
100\end{array}$ & $\begin{array}{l}0.00 \\
0.13 \pm 0,31 \\
0.32 \pm 0.67 \\
0.30 \pm 0.28\end{array}$ & $\begin{array}{l}0.0 \\
2.7 \\
12.4 \\
\text { na }\end{array}$ & $\begin{array}{l}0.00 \\
<0.01 \\
0.01 \\
0.01\end{array}$ & $\begin{array}{l}0.0 \\
2.6 \\
12.2 \\
\text { na }\end{array}$ & $\begin{array}{l}0.00 \\
0.01 \pm 0.10 \\
0.12 \pm 0.50 \\
0.30 \pm 0.05\end{array}$ \\
\hline Galapagos Islands & & & & & & & & & & \\
\hline $\mathrm{P}^{14}$-Puerto Ayora $(-650,453,109039)$ & $\begin{array}{l}\text { P. columellaris } \\
\text { P. patula } \\
\text { T. melones } \\
\text { T. brevidentata }\end{array}$ & $\begin{array}{l}16 / 6 \\
5 / 3 \\
11 / 19 \\
11 / 19\end{array}$ & $\begin{array}{l}24.3 \pm 1.1 \\
21.5 \pm 0.5 \\
22.8 \pm 1.0 \\
24.8 \pm 2.6\end{array}$ & $\begin{array}{l}23.9 \pm 3.4 \\
25.0 \pm 0.5 \\
23.6 \pm 1.0 \\
28.6 \pm 2.9\end{array}$ & $\begin{array}{l}83 \\
100 \\
5 \\
21\end{array}$ & $\begin{array}{l}0.77 \pm 0.74 \\
0.40 \pm 0.52 \\
0.03 \pm 0.11 \\
0.27 \pm 0.73\end{array}$ & $\begin{array}{l}6.2 \\
3.2 \\
0.3 \\
0.9\end{array}$ & $\begin{array}{l}0.03 \\
0.03 \\
0.01 \\
0.01\end{array}$ & $\begin{array}{l}6.1 \\
3.7 \\
0.3 \\
1.0\end{array}$ & $\begin{array}{l}0.65 \pm 0.55 \\
0.54 \pm 0.53 \\
0.01 \pm 0.4 \\
0.15 \pm 0.80\end{array}$ \\
\hline $\begin{array}{l}\mathrm{P}^{15} \text {-Puerto Baquerizo Moreno } \\
\quad(-650,453,109039)\end{array}$ & $\begin{array}{l}\text { P. columellaris } \\
\text { P. patula } \\
\text { T. melones }\end{array}$ & $\begin{array}{l}13 / 7 \\
5 / 4 \\
12 / 18\end{array}$ & $\begin{array}{l}30.2 \pm 2.9 \\
28.9 \pm 1.5 \\
27.3 \pm 0.9\end{array}$ & $\begin{array}{l}32.4 \pm 3.2 \\
28.9 \pm 2.1 \\
27.8 \pm 0.3\end{array}$ & $\begin{array}{l}14 \\
0 \\
11\end{array}$ & $\begin{array}{l}0.14 \pm 0.38 \\
0.00 \\
0.17 \pm 0.51\end{array}$ & $\begin{array}{l}1.5 \\
0.0 \\
2.4\end{array}$ & $\begin{array}{l}<0.01 \\
0.00 \\
<0.01\end{array}$ & $\begin{array}{l}1.6 \\
0.0 \\
2.4\end{array}$ & $\begin{array}{l}0.08 \pm 0.50 \\
0.00 \\
0.03 \pm 0.35\end{array}$ \\
\hline $\mathrm{P}^{16}$-Puerto Grande (-650,453,109039) & $\begin{array}{l}\text { P. patula } \\
\text { T. melones } \\
\text { T. brevidentata }\end{array}$ & $\begin{array}{l}1 / 2 \\
13 / 15 \\
10 / 18\end{array}$ & $\begin{array}{l}22.5 \pm 0.4 \\
26.1 \pm 1.4 \\
25.8 \pm 2.1\end{array}$ & $\begin{array}{l}32.5 \pm 0.9 \\
26.8 \pm 2.2 \\
23.9 \pm 2.5\end{array}$ & $\begin{array}{l}50 \\
27 \\
33\end{array}$ & $\begin{array}{l}0.50 \pm 0.71 \\
0.27 \pm 0.50 \\
0.35 \pm 0.68\end{array}$ & $\begin{array}{l}20.0 \\
5.1 \\
8.8\end{array}$ & $\begin{array}{l}0.02 \\
0.01 \\
0.01\end{array}$ & $\begin{array}{l}28.9 \\
5.2 \\
8.2\end{array}$ & $\begin{array}{l}0.45 \pm 0.55 \\
0.15 \pm 0.42 \\
0.25 \pm 0.44\end{array}$ \\
\hline
\end{tabular}




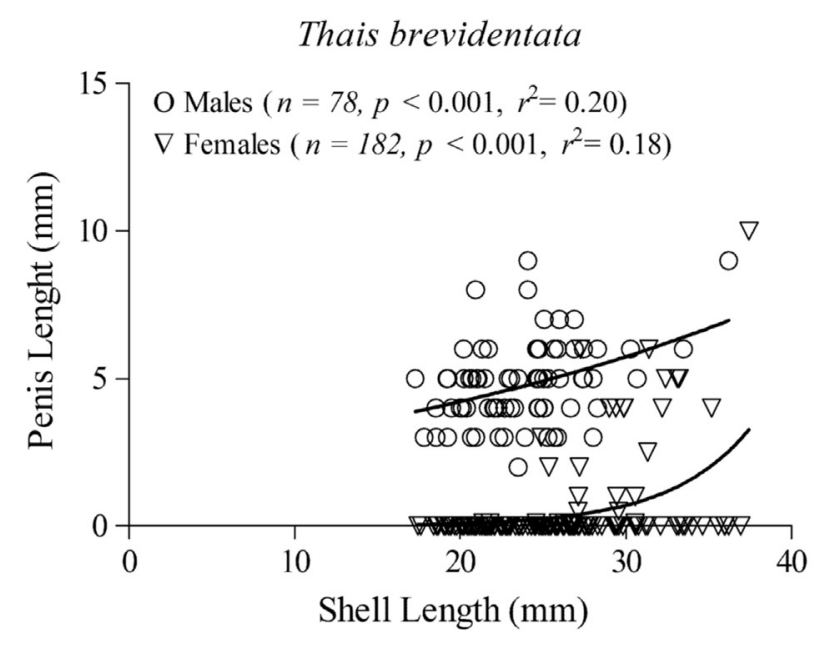

\section{Thais kiosquiformis}

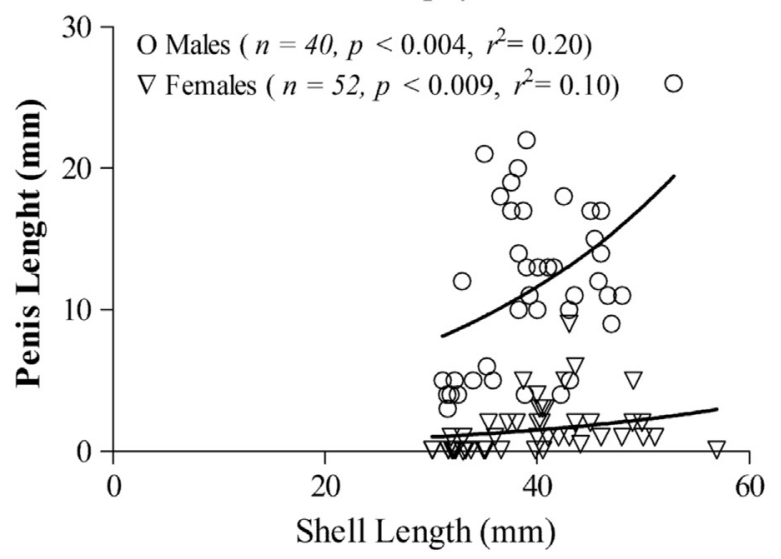

Plicopurpura pansa

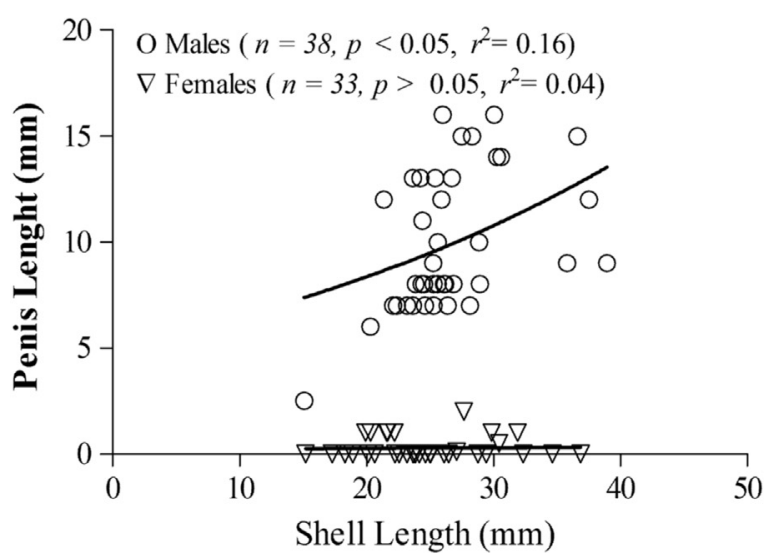

Thais biserialis

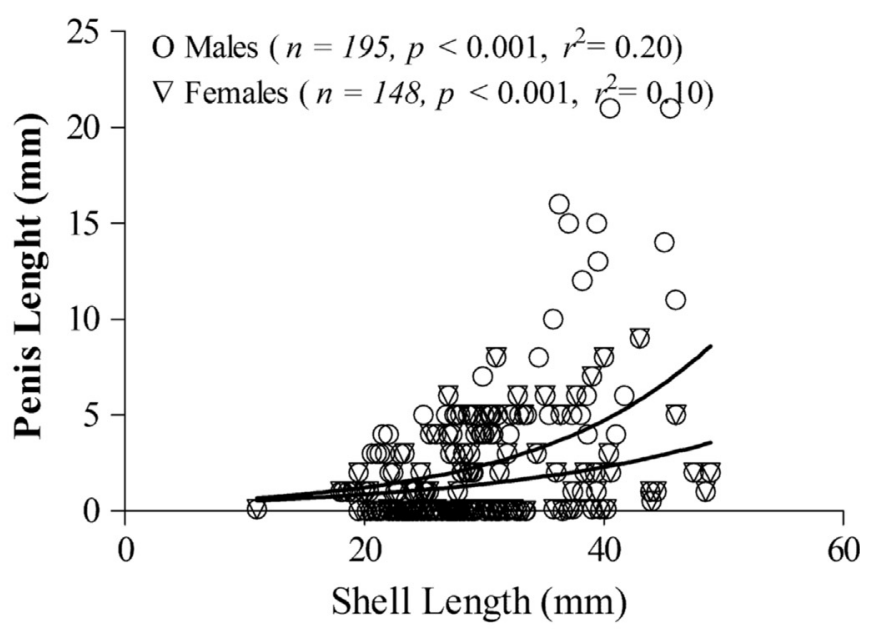

Thais melones

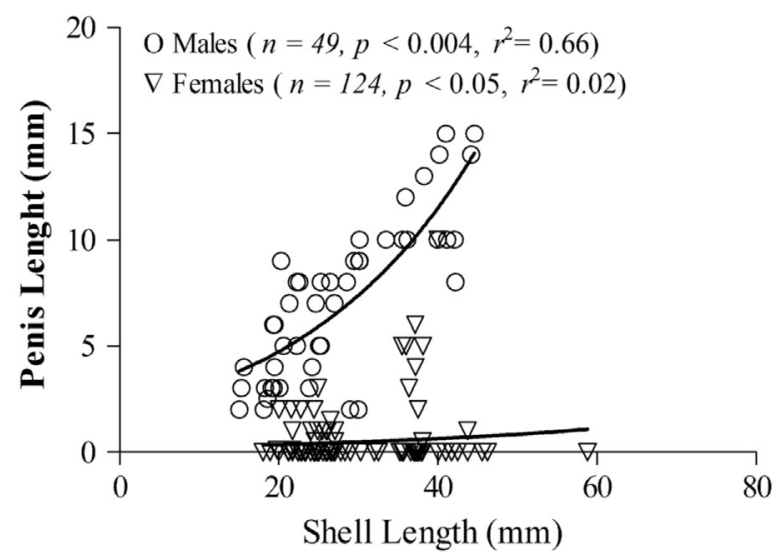

Plicopurpura columellaris

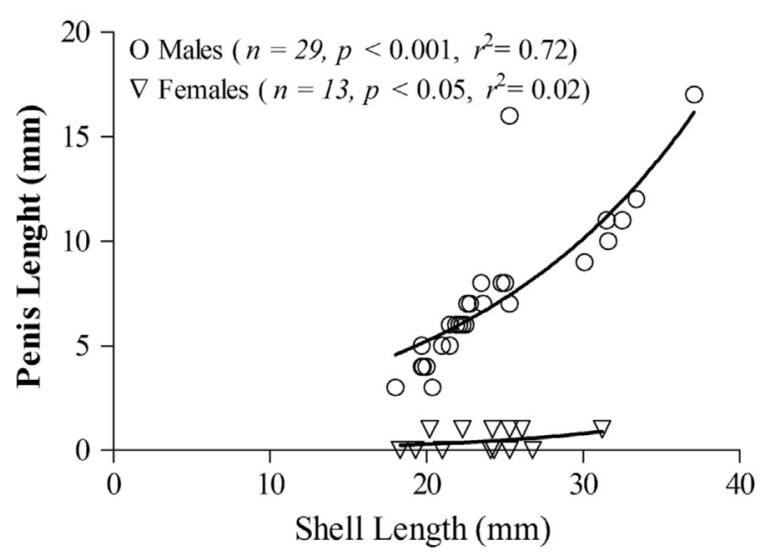

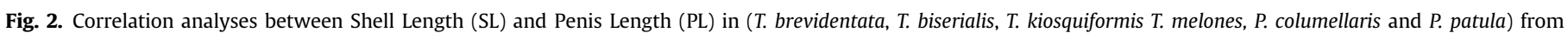
Ecuadorian coastal shore and Galapagos islands.

coastal shores and Galapagos islands. Similarity, SL differences were also detected among the samples collected in the present study and those obtained in 2009 (Kruskal-Wallis, $p<0.05$ ) by Castro et al. [17]. Similar situation was previously reported for the muricids Bolinus brandaris from Ria Formosa (Algarve, southern Portugal) [25] and Thais chocolata from Peru [18]. These studies, suggest that assessment of imposex spatial variations should include robust and reliable indices, such standardized RPLI. Thus, in the present study, RPLI and FPLI values were standardized by SL, preventing biased analysis.

Tributyltin concentrations in environmental samples are frequently well correlated with RPLI values [26] and also SL standardized data [27]. The RPLI is an imposex parameter that roughly balances the penis sizes of males and females at each site, being less affected by inter-individual variability than vas deferens sequence index (VDSI) [28]. Thus, relative penis indices have been 
confirmed to be more responsive to TBT contamination than VDSI.

\subsection{Spatial and temporal distribution of Imposex in Ecuadorian coastal areas}

Imposex incidence in the five muricid species was detected in all studied areas from Ecuadorian coastal shore (Table 1). In our concern, this is a first imposex report for T. melones. On the other hand, imposex occurrence had already been reported in Thais. kiosquiformis, T. biserialis and T. brevidentata from Ecuadorian coastal areas [17]. The higher imposex values (considering all indices) were detected in Bolivar harbor $-\mathrm{P}^{1}$ in $T$. biseralis $(\mathrm{I} \%=100$, $\mathrm{FPLI}_{\text {stand }}=0.0, \mathrm{RPLI}_{\text {stand }}=15.0$ and VDSI $=2.05$ ) and $T$. kiosquiformis (I \%=100, FPLI $_{\text {stand }}=0.08, \mathrm{RPLI}_{\text {stand }}=20.7$ and VDSI $=2.89$ ); Guayaquil harbor $-\mathrm{P}^{3}$ in $T$. kiosquiformis ( $\%=94, \mathrm{FPLI}_{\text {stand }}=0.04$, $\mathrm{RPLI}_{\text {stand }}=10.3$ and VDSI $\left.=0.96\right)$; Porsoja $-\mathrm{P}^{4}$ in $T$. biserialis $(\mathrm{I} \%=$ $100, \mathrm{FPLI}_{\text {stand }}=0.01, \mathrm{RPLI}_{\text {stand }}=5.9$ and VDSI $\left.=0.20\right)$ and $T$. kiosquiformis ( $\mathrm{I} \%=100, \mathrm{FPLI}_{\text {stand }}=0.07, \mathrm{RPLI}_{\text {stand }}=58.5$ and VDSI $=2.12$ ) (Table 1 ). As had been previously observed by Castro et al. [17] these areas located inside Guayaquil gulf and under influence of largest commercial harbors of Ecuador [19], are probably relevant TBT sources for adjacent coastal environments. Furthermore, imposex levels were found in $T$. brevidentata, $T$. biserialis, $T$. kiosquiformis and T. melones in the central and northern regions of Ecuador, expanding the coastal area of the Pacific ocean known for occurrence of impacts related to TBT contamination and confirming the widespread problem throughout south American coast [4].

Reductions in the imposex levels have been reported worldwide $[13,29]$. However, studies on temporal and spatial trends of imposex parameters are frequently affected by animal biometric variations, including the relationship between SL and PL [24]. Thus, some precautions were taken to minimize misinterpretations in the trends of imposex levels in the present study. Firstly, the sampling was conducted in the same season to avoid seasonal variability in the PL, which is regulated by reproductive cycle of muricid species [28]. This problem was previously reported in Bolinus brandaris and may affect imposex assessments [24]. Moreover, as shown in studied muricid species PL is affected by SL. Therefore, for temporal evaluations of imposex incidence in the present study was used a SL standardized RPLI (RPLI stand $_{\text {) ac- }}$ cording recommended by Castro and Fillmann, 2012 for muricid species [18]. Considering RPLI ${ }_{\text {stand }}$ and VDSI values obtained for eight sampled sites $\left(\mathrm{P}^{1}, \mathrm{P}^{3}, \mathrm{P}^{4}, \mathrm{P}^{5}, \mathrm{P}^{6}, \mathrm{P}^{7}, \mathrm{P}^{8}\right.$ and $\left.\mathrm{P}^{9}\right)$, which were sampled using the same species during the years 2009 and 2012, there were expressive reductions in imposex incidence (Fig. 3). In $\mathrm{P}^{5}$ and $\mathrm{P}^{9}$, no imposex signs were detected in T. brevidentata during the sampling performed in 2012, although low levels have been observed in 2009. Similarly, in $\mathrm{P}^{1}, \mathrm{P}^{3}, \mathrm{P}^{4}, \mathrm{P}^{6}, \mathrm{P}^{7}$ and $\mathrm{P}^{8}$ sites (using $T$. brevidentata, T. biserialis and T. kiosquiformis) the imposex levels also showed a reduction during studied period. The most significant reductions were observed in $\mathrm{P}^{1}, \mathrm{P}^{3}$ and $\mathrm{P}^{4}$ stations where $\mathrm{RPLI}_{\text {stand }}$ values decreased from 32.8, 23.1 and 28.5 in 2009-20.7, 10.6 and 5.9 in 2012, respectively. Similarity, VDSI values showed a statistically significant reduction (Mann-Whitney $U$ test, $\mathrm{p}<0.05$ ) all sampled sites. These sampling sites, particularly, are located near to main potential TBT sources the environment (Guayaquil and Bolivar harbors). Thus, the observed reduction in imposex levels should be probably related to the global ban issued by IMO at 2008, since large vessels from countries signatories of the AFS convention stopped using antifouling TBT-based since 2008. However, the moderate imposex levels currently reported in present study indicates that TBT environmental concentrations are still high enough to produce biological effects in studied areas. This observation may be related to the massive presence of pleasure and fishing boats in coastal areas from Ecuador, which according to a recent study performed in Venezuelan coast, are the new TBT sources for South American coastal systems [26]. In fact, reductions in imposex and TBT levels is expected in every ocean around the world soon after the implementation of AFS convention. However, the speed and effectiveness of this reducing trend
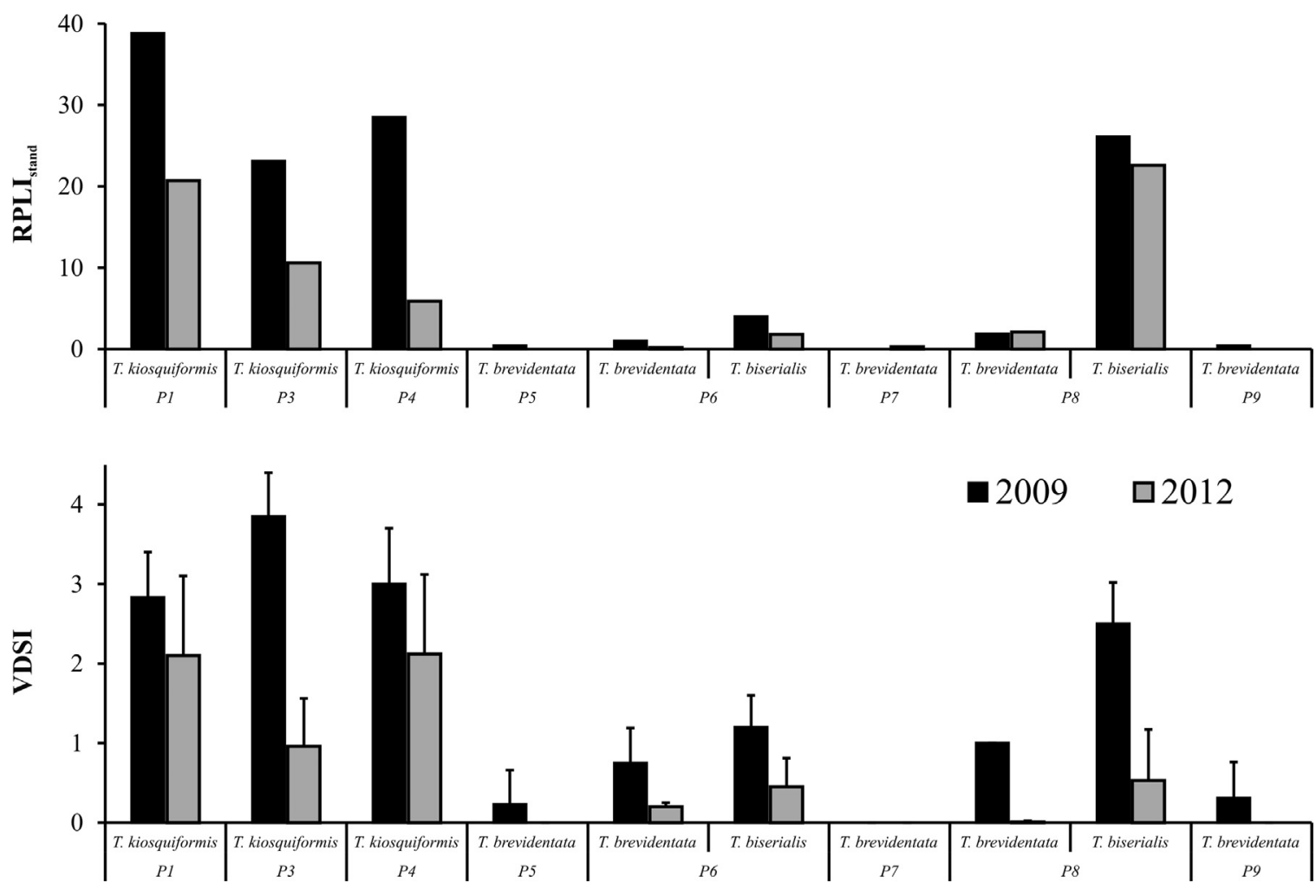

Fig. 3. Imposex (RPLI $I_{\text {stand }}$ and VDSI) reduction in muricid species from Ecuadorian coastal areas between 2009 and 2012. 
will depend on the effectiveness of global and local TBT regulations [18]. Therefore, in Ecuadorian coastal shore the imposex reduction seems to be occurring more slowly than European and North American countries.

\subsection{Imposex incidence in Galapagos Islands}

In Galapagos islands, the imposex incidence was detected in three species from all sampled sites. The high levels were observed in $P$. patula $(\mathrm{I} \%=100$, RPLI $=3.2$ and VDSI $=0.54)$ and $P$. columellaris $(\mathrm{I} \%=83, \mathrm{RPLI}=6.2$ and VDSI $=0.65)$ from Puerto Ayora (P14). In that station, lower imposex levels were also detected in $T$. brevidentata $(\mathrm{I} \%=21, \mathrm{RPLI}=0.9$ and VDSI $=0.15)$ and $T$. melones $(\mathrm{I} \%=5, \mathrm{RPLI}=0.3$ and VDSI $=0.01)$. At Puerto Baquerizo Moreno, the imposex values to $P$. columellaris $(\mathrm{I} \%=14, \mathrm{RPLI}=1.5$ and VDSI $=0.08)$ and $T$. melones $(\mathrm{I} \%=11, \mathrm{RPLI}=2.4$, and VDSI $=0.03)$ were lower. In addition, in this site, no imposex signs were observed in P. patula. In Puerto Grande the high imposex incidence was $1 \%=$ $50 \%$, RPLI $=20.0$ and VDSI $=0.45$ in $P$. patula. Imposex incidence had already been reported to $P$. patula and $T$. brevidentata from South American coastal areas. However, in our concern, this is the first imposex report for $P$. columellaris and $T$. melones. Despite not having been performed chemical analysis of butyltin compounds in the obtained samples, the imposex occurrence is a clear indication that Galapagos islands are exposed to TBT contamination probable from antifouling systems used in ships and boats [12].

Chemical contamination has been recently reported in several marine protected areas from South America [30-32], including TBT environmental levels and impacts (imposex) in Paraty island (Brazil) [14], Mochima National Park (Venezuela) [25] and Argentine Patagonian coast [33]. The unexpected imposex occurrence in four muricid species from Galapagos Islands indicates that, despite the global TBT ban, environmental issues related to antifouling paints TBT-based still were not overcome, at least in South American coastal areas. In addition, these results can act as a useful baseline for the assessment of the future trends in TBT contamination in that area, contributing to verify the effectiveness of restrictive regulations on the use of antifouling paints TBTbased. Achieving consensus on equitable and effective national and global regulations for the use of organotins as biocides in antifouling systems have proven to be very complex and difficult task in a globalized world, the Galapagos Island and the Ecuadorian coast is not an exception.

Unlike other oceanic archipelagos where conservation instruments are still emerging, the Galapagos archipelago has almost 97\% of land protected as National Park [34]. Situated in the Pacific Ocean from the Ecuadorian coast, the Galapagos Islands were recognized in 1978 as a world heritage site and in 1985, as a biosphere reserve by UNESCO. Only almost a decade later, in 2001, UNESCO's World Heritage Site declaration was expanded to include the Galapagos Marine Reserve [35]. Despite of having a protected area of $138,000 \mathrm{~km}^{2}$, only $6 \%$ of the Marine Reserve is designated entirely for conservation, and $11 \%$ is designed for tourism, yet extractive activities such as fishing are not allowed [36].

Despite international efforts, Galapagos is experiencing an environmental crisis due to population growth, increasing tourism, diversification of economic activities, bioinvasions and environmental contamination [29]. Promoting socioeconomic development throughout activities such as tourism while meeting conservation goals has always been a historical challenge in Galapagos [37]. Although tourism and its associated services can, however, act as a means of environmental protection, the increase in larger passenger vessels, small tour boats and private yachts cruising the Galapagos water can also represent a silent and diffuse threat to marine biodiversity and long-term sustainability [36]. Additionally, there is still the unsolved problem of illegal commercial fishing vessels throughout the reserve [36].

In 2007, as a result of UNESCO's decision to place the Islands on the List of World Heritage Sites in Danger, the Ecuadorian Government developed a series of strategies (e.g. tourism management, immigration control, invasive species management and long-term development planning) to reverse this situation and to improve the effectiveness of the marine reserve [36]. As a consequence, Galapagos recovered its World Heritage status in 2010, yet the mentioned threats still require further action and the risk still remains despite islands' the permit system [36,38]. Studies on carrying capacity stipulate acceptable numbers of visitors and the specific sites to be visited $[35,38]$. Trips became shorter, however there are now greater number of tours. In this context, not only the already known impacts posed by contaminated ballast water and invasive species remains, but other previously unknown threats caused by antifouling paints TBT-based require attention and need to be incorporated in current and future management plans [39].

As a complex social-ecological system, Galapagos requires novel ways and conservation instruments to protect its pristine resources and long-term sustainability [34]. Studies on TBT contamination resulting from the use of antifouling paints TBT-based and its relation with imposex disorder provide a solid scientific basis for the development of more effective management tools for monitoring of TBT pollution. It also should provide valuable evidence-based information for countries such as Ecuador which still are not signatories to the IMO (International Marine Organization) AFS Convention [20]. Ratified by 71 states as of August 2015, including 69 United Nations member states plus the Cook Islands and Niue (Hassan \& Hassan, 2016), the AFS Convention prohibits the use of harmful organotins in antifouling paints used on ships and establishes mechanisms to prevent the use of other harmful substances in antifouling systems [20,39].

\subsection{Preliminary assessment of imposex sensitivity}

Biomonitoring studies are frequently hampered by the spatial distribution of bioindicator species which is influenced by several environmental characteristics [31]. Thus, it is often necessary to use different species to cover large coastal areas [32]. However, in order to provide relevant information about the imposex response of bioindicator species, comparative evaluations are useful [33] even when species of the same genus are used [34]. In the present study, two or three different muricid species were simultaneously sampled at $\mathrm{P}^{1}, \mathrm{P}^{2}, \mathrm{P}^{4}, \mathrm{P}^{5}, \mathrm{P}^{6}, \mathrm{P}^{7}, \mathrm{P}^{8}, \mathrm{P}^{9}, \mathrm{P}^{10}$, and $\mathrm{P}^{12}$. A preliminary appraisal on their relative sensitivity was performed based in $\mathrm{RPLI}_{\text {stand }}$ values, assuming these organisms were equally exposed to TBT contamination. The results indicated that Thais kiosquiformis is likely to be the most sensitive species to TBT, followed by Thais biserialis, Thais brevidentata and Thais melones (Fig. 4). Several comparative studies on sensitivity for imposex responses have been performed in different gastropod species [17,32,35]. The observed differences may be explained generally by differential physiological responses, bioaccumulation factors or excretion rates for xenobiotics, or even due specific feeding habits [36]. It is worth noting, that while biomonitoring studies should always prefer the most sensitive species. These, should also be abundant and broadly distributed to make the study viable. When these last conditions cannot be satisfied, it would be preferable to use a less sensitive but more abundant species. Therefore, considering the geographical distribution, $T$. kiosquiformis seems to be the best TBT sentinel in areas inside Guayaquil gulf. However, in exposed coastal areas such as outside Guayaquil gulf and Galapagos Islands, where T. kiosquiformis have limited occurrence, $T$. biserialis and $T$. brevidentata should be preferentially used, since present high sensibility linked to wide distribution [37]. Furthermore, experimental studies should be 


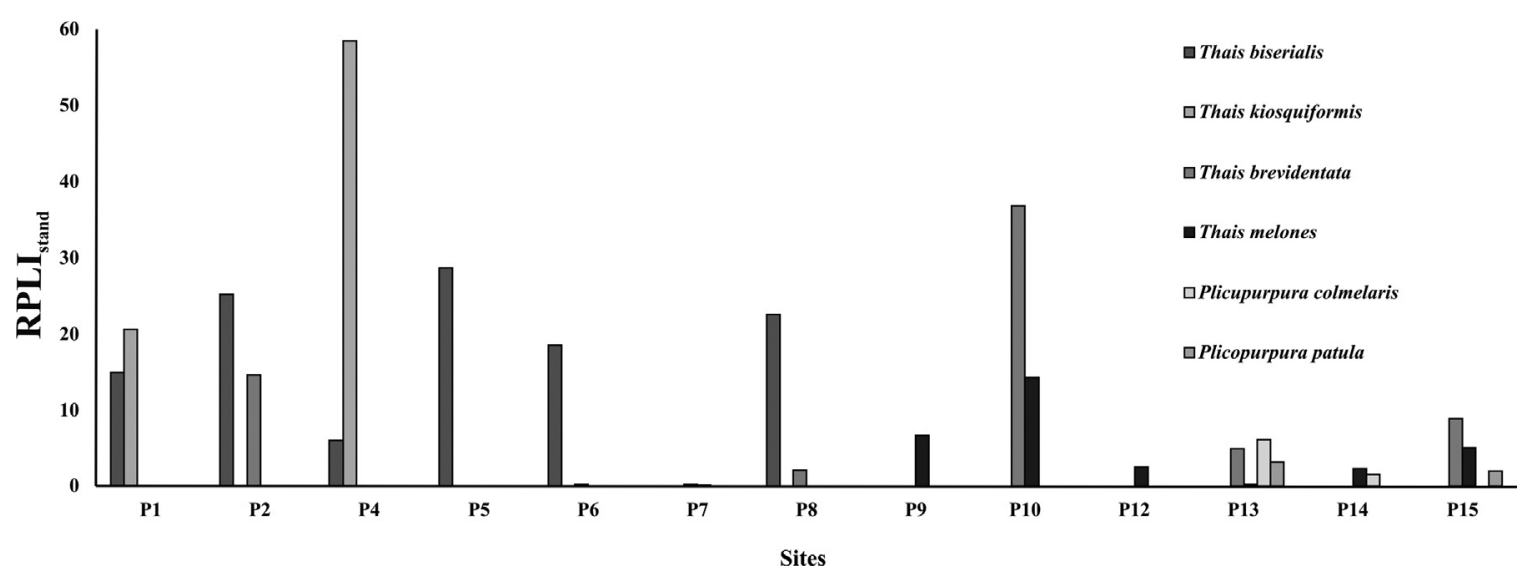

Fig. 4. Relative sensibility evaluation of $\mathrm{RPLI}_{\mathrm{Stand}}$ values for Thais kiosquiformis, Thais biserialis, Thais brevidentata and Thais melones.

performed using these muricid species in order to estimate rates of imposex developing. This information could be useful in evaluations of temporal trends of TBT pollution using imposex as biomarker [32].

\section{Conclusions}

The imposex occurrence was detected in all sampled sites along Ecuadorian shore even after global TBT ban. Thus, though its incidence has reduced in studied area between 2009 and 2012, TBT environmental effects are still widespread, affecting six muricid species. Considering the geographical occurrence of the muricids, T. kiosquiformis seems to be the best indicator for evaluation in sheltered areas (such as estuaries, gulfs and bays). On the other hand, $T$. biserialis and $T$. brevidentata should be preferentially used in monitoring studies of exposed coastal zones.

In addition, imposex incidence in four muricid species from Galapagos islands were detected suggesting that this marine protected area is under threat of antifouling contamination. These findings, after TBT global ban, denotes that current regulations and conservation plans still need to address such an issue and incorporate more restrictive management rules, particularly in complex coastal areas, vulnerable and unique systems such as the Galapagos Islands.

\section{References}

[1] A. Kotrikla, Environmental management aspects for TBT antifouling wastes from the shipyards, J. Environ. Manag. 90 (2009) S77-S85.

[2] Í.B. Castro, E. Westphal, G. Fillmann, Tintas anti-incrustantes de terceira geração: novos biocidas no ambiente aquático, Quím. Nova. 34 (2011) 1021-1031.

[3] E. Almeida, T.C. Diamantino, O. de Sousa, Marine paints: the particular case of antifouling paints, Prog. Org. Coat. 59 (2007) 2-20.

[4] I.B. Castro, F. Perina, G. Fillmann, Organotin contamination in South American coastal areas, Environ. Monit. Assess. 184 (2012) 1781-1799.

[5] C. Alzieu, Environmental impact of TBT: the French experience, Sci. Total Environ. 258 (2000) 99-102.

[6] K. O'Halloran, J.T. Ahokas, P.F.A. Wright, Response of fish immune cells to in vitro organotin exposures, Aquat. Toxicol. 40 (1998) 141-156.

[7] I.B. Castro, C.A. Rocha-Barreira, M.A. Fernandez, G. Bigatti, Transplant bioassay induces different imposex responses in two species of the genus Stramonita, Mar. Biol. Res. 8 (2012) 397-404.

[8] G.W. Bryan, P.E. Gibbs, L.G. Hummerstone, G.R. Burt, The decline of the gastropod Nucella lapillus around Southwest England - evidence for the effect of Tributyltin from antifouling paints, J. Mar. Biol. Assoc. U. K. 66 (1986) 611-640.

[9] IMO, Summary of the status of conventions as at 31 May 2007, International Maritime Organization, United Kingdom, 2008.

[10] M.H. Depledge, Z. Billinghurst, Ecological significance of endocrine disruption in marine invertebrates, Mar. Pollut. Bull. 39 (1999) 32-38.

[11] M. Rossato, I.B. Castro, C.L. Paganini, E.P. Colares, G. Fillmann, G.L.L. Pinho, Sex steroid imbalances in the muricid Stramonita haemastoma from TBT contaminated sites, Environ. Sci. Pollut. Res. (2016) 1-8, http://dx.doi.org/ $10.1007 /$ s11356-015-5942-0.

[12] P. Matthiessen, P.E. Gibbs, Critical appraisal of the evidence for tributyltinmediated endocrine disruption in mollusks, Environ. Toxicol. Chem. 17 (1998) $37-43$.

[13] Í.B. Castro, M. Rossato, G. Fillmann, Imposex reduction and residual butyltin contamination in southern Brazilian harbors, Environ. Toxicol. Chem. 31 (2012) 947-954.

[14] C.L.L. Borges, M.A.S. Fernandez, Í.B. Castro, G. Fillmann, Organotin pollution from pleasure craft at Paraty, a tourist area of Southeastern Brazil: amelioration or interference? Braz. J. Oceanogr. 61 (2013) 177-186.

[15] D. Azevedo, C.A. Rocha-Barreira, H. Matthews-Cascon, I.B. Castro, Pugilina morio L. a new imposex exhibitor from South American estuarine environments: approach for a non-lethal method to evaluate imposex, Bull. Environ. Contam. Toxicol. 89 (2012) 786-792.

[16] R. Toste, M.A. Fernandez, I.deA. Pessoa, M.A. Parahyba, M.P. Dore, Organotin pollution at Arraial do Cabo, Rio de Janeiro State, Brazil: increasing levels after the TBT ban, Braz. J. Oceanogr. 59 (2011) 111-117.

[17] I.B. Castro, M. Arroyo, P. Costa, G. Fillmann, Butyltin compounds and imposex levels in Ecuador, Arch. Environ. Contam. Toxicol. 62 (2012) 68-77.

[18] Í.B. Castro, G. Fillmann, High tributyltin and imposex levels in the commercial muricid Thais chocolata from two Peruvian harbor areas, Environ. Toxicol. Chem. 31 (2012) 955-960.

[19] M. Herrera, D. Castro, I. Saa, E. Elias, Puertos, caletas y asentamientos artesanales del Ecuador, 2013.

[20] IMO, Status of multilateral Conventions and instruments in respect of which the International Maritime Organization or its Secretary-General performs depositary or other functions, 2014.

[21] M. Huet, P. Fioroni, J. Oehlmann, E. Stroben, Comparison of imposex response in 3 prosobranch species, Hydrobiologia 309 (1995) 29-35.

[22] P.E. Gibbs, G.W. Bryan, Reproductive failure in populations of the dog-whelk, Nucella lapillus, caused by imposex induced by tributyltin from antifouling paints, J. Mar. Biol. Assoc. U.K. 66 (1986) 767-775.

[23] R. Toste, I.A. Pessoa, M.P. Dore, M.A. Parahyba, M.A. Fernandez, Is aphallic vas deferens development in females related to the distance from organotin sources? A study with Stramonita haemastoma, Ecotoxicol. Environ. Saf. 91 (2013) 162-170, http://dx.doi.org/10.1016/j.ecoenv.2013.01.026.

[24] P. Vasconcelos, P. Moura, C. Barroso, M. Gaspar, Size matters: importance of penis length variation on reproduction studies and imposex monitoring in Bolinus brandaris (Gastropoda: Muricidae), Hydrobiologia 661 (2011) 363-375.

[25] P. Vasconcelos, M.B. Gaspar, C.M. Barroso, Imposex in Bolinus brandaris from the Ria formosa lagoon (southern Portugal): usefulness of "single-site baselines" for environmental monitoring, J. Environ. Monit., 2010.

[26] C.A. Paz-Villarraga, Í.B. Castro, P. Miloslavich, G. Fillmann, Venezuelan Caribbean Sea under the threat of TBT, Chemosphere 119 (2015) 704-710.

[27] M. Petracco, R. Camargo, T. Berenguel, N.L.P. de Arruda, L. del Matto, L. Amado et al., Evaluation of the use of Olivella minuta (Gastropoda, Olividae) and Hastula cinerea (Gastropoda, Terebridae) as TBT sentinels for sandy coastal habitats, Environ. Monit. Assess. 187 (2015) 1-11, http://dx.doi.org/10.1007/ s10661-015-4650-Z

[28] S. Galante-Oliveira, I. Oliveira, J.A. Santos, M. de Lourdes Pereira, M. Pacheco, C. M. Barroso, Factors affecting RPSI in imposex monitoring studies using Nucella lapillus (L.) as bioindicator, J. Environ. Monit. 12 (2010) 1055-1063.

[29] M.E. Waite, M.J. Waldock, J.E. Thain, D.J. Smith, S.M. Milton, Reductions in TBT concentrations in UK estuaries following legislation in 1986 and 1987, Mar. Environ. Res. 32 (1991) 89-111.

[30] G.S. Araujo, L.B. Moreira, R.D. Morais, M.B. Davanso, T.F. Garcia, A.C.F. Cruz, et al., Ecotoxicological assessment of sediments from an urban marine protected area (Xixová-Japuí State Park, SP, Brazil), Mar. Pollut. Bull. 75 (2013) 62-68, http://dx.doi.org/10.1016/j.marpolbul.2013.08.005.

[31] A.C.F. Cruz, M.B. Davanso, G.S. Araujo, L.M. Buruaem, S.T. Santaella, R.D. Morais, et al., Cumulative influences of a small city and former mining activities on the 
sediment quality of a subtropical estuarine protected area, Environ. Monit. Assess. 186 (2014) 7035-7046, http://dx.doi.org/10.1007/s10661-014-3908-1.

[32] N.T. Hoff, R.C.L. Figueira, D.M.S. Abessa, Levels of metals, arsenic and phosphorus in sediments from two sectors of a Brazilian Marine Protected Area (Tupinambás Ecological Station), Mar. Pollut. Bull. 91 (2015) 403-409, http: //dx.doi.org/10.1016/j.marpolbul.2014.10.044.

[33] M.G. Commendatore, M.A. Franco, P. Gomes Costa, I.B. Castro, G. Fillmann, G. Bigatti, et al., Butyltins, polyaromatic hydrocarbons, organochlorine pesticides, and polychlorinated biphenyls in sediments and bivalve mollusks in a mid-latitude environment from the Patagonian coastal zone, Environ. Toxicol Chem. 34 (2015) 2750-2763, http://dx.doi.org/10.1002/etc.3134.

[34] J. González, C. Montes, J. Rodrígues, W. Tapia, Rethinking the Galápagos Islands as a complex social-ecological system: implications for conservation and management, Ecol. Soc. 13 (2008) 1-13.

[35] B. Epler, Tourism, the economy, population growth, and conservation in Galapagos, Charles Darwin Found, 2007.

[36] P.J. Jones, A governance analysis of the Galápagos Marine Reserve, Mar. Policy 41 (2013) 65-71.

[37] R.A. Kenchington, Tourism in the Galapagos Islands: the dilemma of conservation, Environ. Conserv. 16 (1989) 227-232.

[38] C.V. Mejía, S. Brandt, Managing tourism in the Galapagos Islands through price incentives: a choice experiment approach, Ecol. Econ. 117 (2015) 1-11.

[39] S. Sonak, P. Pangam, A. Giriyan, K. Hawaldar, Implications of the ban on organotins for protection of global coastal and marine ecology, J. Environ. Manag. 90 (2009) S96-S108. 